\title{
JURIIII
}

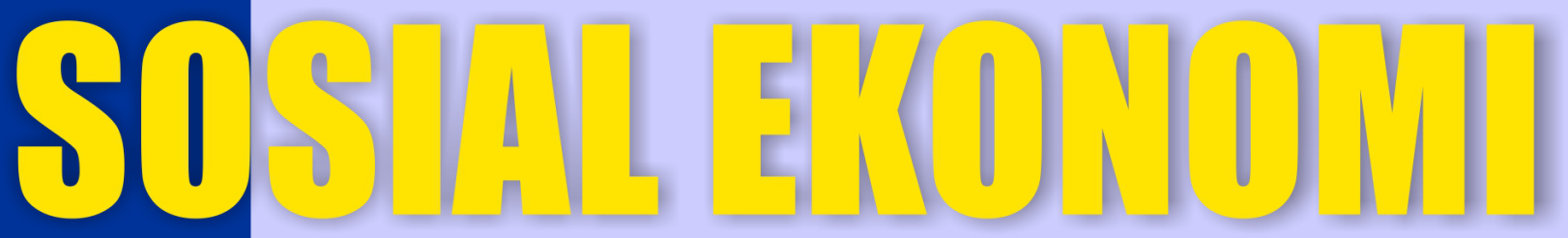

\section{KELAUTAN DAWMPRINAWAN}

\begin{tabular}{|c|c|c|c|c|c|}
\hline $\begin{array}{c}\text { J. Sosial Ekonomi } \\
\text { Kelautan dan Perikanan }\end{array}$ & Vol. 13 & No. 2 & Hal. 133-248 & $\begin{array}{c}\text { Jakarta } \\
\text { Desember 2018 }\end{array}$ & $\begin{array}{c}\text { ISSN } \\
\text { 2088-8449 }\end{array}$ \\
\hline
\end{tabular}

Terakreditasi RISTEKDIKTI : 30/E/KPT/2018

Diterbitkan bersama :

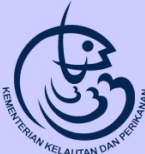

Balai Besar Riset Sosial Ekonomi Kelautan dan Perikanan

\section{MFISERN}

Jaringan Riset Sosial Ekonom Kelautan dan Perikanan 


\title{
JURNAL SOSIAL EKONOMI KELAUTAN DAN PERIKANAN
}

\author{
Volume 13 Nomor 2, Desember 2018 \\ Penanggung Jawab : \\ Kepala Balai Besar Riset Sosial Ekonomi Kelautan dan Perikanan
}

Dewan Redaksi :

Ketua:

Prof. Dr. Sonny Koeshendrajana (Ekonomi Sumber Daya Kelautan dan Perikanan)

\section{Anggota:}

Prof. Dr. I. Wayan Rusastra (Ekonomi Pertanian)

Dr. Achmad Zamroni (Pengelolaan Wilayah Pesisir)

Dr. Rilus A. Kinseng (Sosiologi)

Dr. Zuzy Anna (Ekonomi Sumber Daya Alam)

\section{Redaksi Pelaksana :}

Sinta Nurwijayanti, S. Pi, M. SE., M.A

Tenny Apriliani, M. Si

Risna Yusuf, M. Si

Nila Mustikawati, S.S

Permana Ari Soejarwo, S. Kel, M.T

Edwin Yulia Setyawan, S.T

Nurhendra S. Kom

Ilham Ferbiansyah, S. Kom

Rahadi Susetyo Frendly Muhammad, S. Ikom

\author{
Alamat Redaksi : \\ Balai Besar Riset Sosial Ekonomi Kelautan dan Perikanan \\ Gedung BRSDM KP Lt. 3 \\ Jalan Pasir Putih Nomor 1 Ancol Timur, Jakarta Utara \\ Telp. (021) 6471 1583, Faks.(021) 64700924 \\ Email: pt.sosek@gmail.com \\ Jurnal Online: $h$ ttp://ejournal-balitbang.kkp.go.id/index.php/sosek
}




\section{MITRA BEBESTARI \\ JURNAL SOSIAL EKONOMI KELAUTAN DAN PERIKANAN \\ (JSEKP)}

1. Prof. Dr. Agus Heri Purnomo (Ekonomi Sumber Daya Alam - Kementerian Kelautan dan Perikanan)

2. Prof. Dr. Pantjar Simatupang (Ekonomi Pertanian - Pusat Sosial Ekonomi dan Kebijakan Pertanian)

3. Prof. Dr. Tridoyo Kusumastanto (Kebijakan Kelautan dan Perikanan - Institut Pertanian Bogor)

4. Prof. Dr. Ir. Hermanto Siregar, M.Ec (Makroekonomi, Ekonometrika - Institut Pertanian Bogor)

5. Prof. Dr. Ir. Nuddin Harahab, MP (Ekonomi Sumberdaya Perikanan - Universitas Brawijaya)

6. Dr. Arif Satria (Kebijakan Kelautan dan Perikanan - Institut Pertanian Bogor)

7. Dr. Luky Adrianto (Ekonomi Ekologi - Institut Pertanian Bogor)

8. Dr. Ir. Achmad Fahrudin, M.Si (Pengelolaan Pesisir - Institut Pertanian Bogor)

9. Dr. Dedi Supriadi Adhuri (Antropologi Maritim - Lembaga IImu Pengetahuan Indonesia)

10. Dr. Ir. Eddy Afrianto, M. Si (Pengelolaan Pascapanen Produk Perikanan - Universitas Padjajaran)

11. Dr. Ir. Edi Susilo, MS (Kebijakan Pembangunan Perikanan - Universitas Brawijaya)

12. Dr. Yudi Wahyudin (Kebijakan Pembangunan dan Ekonomi Pesisir dan Lautan - Intitut Pertanian Bogor)

13. Dr. Ir. Pudji Purwanti, MP (Ekonomi Perikanan - Universitas Brawijaya)

14. Dr. Najamuddin, ST, M.Si (IImu Kelautan \& Lingkungan - Universitas Khairun)

15. La Ode Muh. Yasir Haya, S.T., M.Si., PhD (IImu Kelautan - Universitas Halu Oleo)

16. Dr. Siti Hajar Suryawati, M.Si (Pengelolaan Sumber Daya Pesisir dan Lautan - Balai Besar Riset Sosial Ekonomi Kelautan dan Perikanan)

17. Dr. Ir. Siti Amanah, MSc. (Komunikasi dan Penyuluhan, Institut Pertanian Bogor)

18. Dr. Asep Agus Handaka, S. Pi, MT (Sosial Ekonomi Perikanan - Universitas Padjadjaran)

19. Ir. Hery Saksono, M.A (Sosiologi dan Ekonomi - Universitas Gajah Mada)

20. Drs. Kusnadi, M.A (Antropolog Maritim - Universitas Jember)

21. Akhmad Solihin, S. Pi, M. H (Teknologi dan Manajemen Perikanan Tangkap - Institut Pertanian Bogor)

22. Drs. Masyhuri Imron, MA, (Sosiologi - Lembaga IImu Pengetahuan Indonesia) 


\section{UCAPAN TERIMA KASIH}

Dewan Redaksi Jurnal Sosial Ekonomi Kelautan dan Perikanan (JSEKP) menyampaikan penghargaan dan terima kasih sebesar - besarnya kepada para Bebestari yang telah berpartisipasi dalam menelaah naskah yang diterbitkan di jurnal ilmiah ini, sehingga jurnal ini dapat terbit tepat pada waktunya. Bebestari yang berpartisipasi dalam terbitan Volume 13 Nomor 2, Desember 2018 adalah:

1. Prof. Dr. Ir. Nuddin Harahab, MP (Ekonomi Sumberdaya Perikanan - Universitas Brawijaya)

2. Prof. Dr. Agus Heri Purnomo (Ekonomi Sumber Daya Alam - Kementerian Kelautan dan Perikanan)

3. Dr. Ir. Achmad Fahrudin, M.Si (Pengelolaan Pesisir - Institut Pertanian Bogor)

4. Dr. Ir. Eddy Afrianto, M. Si (Pengelolaan Pascapanen Produk Perikanan - Universitas Padjajaran)

5. Dr. Ir. Edi Susilo, MS (Kebijakan Pembangunan Perikanan - Universitas Brawijaya)

6. Dr. Ir. Pudji Purwanti, MP (Ekonomi Perikanan - Universitas Brawijaya)

7. Dr. Najamuddin, ST, M.Si (IImu Kelautan \& Lingkungan - Universitas Khairun)

8. Dr. Asep Agus Handaka, S. Pi, MT (Sosial Ekonomi Perikanan - Universitas Padjadjaran)

9. Dr. Ir. Siti Amanah, MSc. (Komunikasi dan Penyuluhan, Institut Pertanian Bogor)

10. Dr. Siti Hajar Suryawati, M.Si (Pengelolaan Sumber Daya Pesisir dan Lautan - Balai Besar Riset Sosial Ekonomi Kelautan dan Perikanan)

11. Ir. Hery Saksono, M.A (Sosiologi dan Ekonomi - Universitas Gajah Mada)

12. Drs. Kusnadi, M.A (Antropolog Maritim - Universitas Jember)

13. Drs. Masyhuri Imron, MA, (Sosiologi - Lembaga IImu Pengetahuan Indonesia)

14. Akhmad Solihin, S. Pi, M. H (Teknologi dan Manajemen Perikanan Tangkap - Institut Pertanian Bogor) 


\section{KATA PENGANTAR}

Puji syukur kami panjatkan kepada Tuhan Yang Maha Esa karena berkat rahmatNya, Jurnal Kebijakan dan Riset Sosial Ekonomi Kelautan dan Perikanan yang berganti nama menjadi Jurnal Sosial Ekonomi Kelautan dan Perikanan dengan tampilan dan tata letak baru telah diterbitkan.

Jurnal Sosial Ekonomi Kelautan dan Perikanan sesuai dengan Keputusan Lembaga IImu Pengetahuan Indonesia 329/E/2016 tertanggal 24 Maret 2016, telah Terakreditasi dengan Nomor Akreditasi: 741/AU3/P2MI-LIPI/04/2016.

Guna peningkatan nilai akreditasi di masa mendatang maka Jurnal Sosial Ekonomi Kelautan dan Perikanan Vol. 13 No. 2 Tahun 2018 telah mengalami perbaikan-perbaikan sesuai dengan saran dan petunjuk dari Tim Akreditasi Jurnal Pusat Dokumentasi IImiah Indonesia - Lembaga IImu Pengetahuan Indonesia (PDII LIPI).

Pada edisi kali ini, ditampilkan sepuluh karya tulis ilmiah yang meliputi; (i) Nilai Ekonomi Ekosistem Terumbu Karang di Taman Wisata Perairan Kapoposang, Sulawesi Selatan; (ii) Aplikasi Model Pella-Tomlinson Pada Pengelolaan Sumber Daya Perikanan Kakap Merah di Indonesia; (iii) Strategi Pengelolaan Perikanan di Waduk Sempor, Kabupaten Kebumen, Provinsi Jawa Tengah; (iv) Deplesi Sumber Daya Ikan Tuna dan Cakalang di Indonesia; (v) Faktor Produksi dan Perkembangan Produksi Usaha Budi Daya Rumput Laut Kotoni di Kabupaten Seram Bagian Barat; (vi) Potensi Pasar Ikan Sagela Asap (Hemirhamphus Sp.) di Provinsi Gorontalo; (vii) Strategi Pengurangan Biaya Logistik Perikanan Lele (Clarias sp.); (viii) Mitigasi Risiko Pada Rantai Pasok Hulu Ikan Scombridae Segar di Pelabuhan Perikanan Pantai Tegal, Jawa Tengah; (ix) Peran Produktif Wanita Pesisir Dalam Menunjang Usaha Perikanan di Kecamatan Tempuran Kabupaten Karawang; (x) Hutang Sebagai Pengikat Hubungan Nelayan dan 'Pengambe' di Kabupaten Jember, Provinsi Jawa Timur.

Dengan diterbitkannya jurnal ini, diharapkan dapat memberikan informasi hasil penelitian di bidang sosial ekonomi yang ada kepada masyarakat dan menambah wawasan ilmu pengetahuan di bidang sosial ekonomi kelautan dan perikanan bagi akademisi dan peneliti. Saran dan masukan dari pembaca sangat diharapkan guna kesempurnaan penerbitan jurnal di masa mendatang. 


\section{JURNAL SOSIAL EKONOMI KELAUTAN DAN PERIKANAN \\ Volume 13 Nomor 2, Tahun 2018}

DAFTAR ISI

Halaman

KATA PENGANTAR

DAFTAR ISI

INDEKS ABSTRAK

iii $-\mathrm{x}$

NILAI EKONOMI EKOSISTEM TERUMBU KARANG

DI TAMAN WISATA PERAIRAN KAPOPOSANG, SULAWESI SELATAN

Oleh : Irwan Muliawan dan Maulana Firdaus

APLIKASI MODEL PELLA -TOMLINSON PADA PENGELOLAAN SUMBER DAYA PERIKANAN KAKAP MERAH DI INDONESIA

Oleh : Sonny Koeshendrajana, Mira, Zuzy Anna, Duto Nugroho, Umi Muwamanah dan Yesi Dewita Sari....

STRATEGI PENGELOLAAN PERIKANAN DI WADUK SEMPOR, KABUPATEN KEBUMEN, PROVINSI JAWA TENGAH

Oleh : Tenny Apriliani, Nendah Kurniasari dan Christina Yuliaty

$153-166$

DEPLESI SUMBER DAYA IKAN TUNA DAN CAKALANG DI INDONESIA

Oleh : Maulana Firdaus, Akhmad Fauzi dan A Faroby Falatehanti

FAKTOR PRODUKSI DAN PERKEMBANGAN PRODUKSI USAHA BUDI DAYA RUMPUT LAUT KOTONI DI KABUPATEN SERAM BAGIAN BARAT

Oleh : Robert Pensa Maryunus, Johanes Hiarieyndan dan Yoisye Lopulalan

POTENSI PASAR IKAN SAGELA ASAP (Hemirhamphus sp.)

DI PROVINSI GORONTALO

Oleh : Ni'mawati Syariah dan Asruddin

$193-203$

STRATEGI PENGURANGAN BIAYA LOGISTIK PERIKANAN LELE (Clarias sp.)

Oleh : Teny Sylvia, Kuncoro Harto Widodo dan Dyah Ismoyowati

$205-218$

MITIGASI RISIKO PADA RANTAI PASOK HULU IKAN SCOMBRIDAE SEGAR

DI PELABUHAN PERIKANAN PANTAI TEGAL, JAWA TENGAH

Oleh : Anjar Kistia Purwaditya, Kuncoro Harto Widodo dan Makhmudun Ainuri

PERAN PRODUKTIF WANITA PESISIR DALAM MENUNJANG USAHA PERIKANAN DI KECAMATAN TEMPURAN KABUPATEN KARAWANG

Oleh : lin Siti Djunaidah dan Nayu Nurmalia

HUTANG SEBAGAI PENGIKAT HUBUNGAN NELAYAN DAN 'PENGAMBE'

DI KABUPATEN JEMBER, PROVINSI JAWA TIMUR

Oleh : Rizky Muhartono dan Nurlaili.... 


\title{
INDEKS ABSTRAK JURNAL SOSIAL EKONOMI KELAUTAN DAN PERIKANAN (ABSTRACT INDEX OF JOURNAL SOCIO-ECONOMICS MARINE AND FISHERIES)
}

Vol. 13 No. 2, Desember 2018

\author{
NILAI EKONOMI EKOSISTEM TERUMBU KARANG \\ DI TAMAN WISATA PERAIRAN KAPOPOSANG, SULAWESI SELATAN \\ Economic Value Of Coral Reef Ecosystem \\ In The Kapoposang Marine Park Conservation, South Sulawesi
}

Irwan Muliawan dan Maulana Firdaus

\begin{abstract}
ABSTRAK
Penilaian terhadap ekosistem pada kawasan konservasi menjadi sangat penting sebagai dasar pertimbangan bagi pengelolaan kawasan konservasi perairan. Kajian ini bertujuan untuk menghitung nilai ekonomi ekosistem terumbu karang di Taman Wisata Perairan (TWP) Kapoposang, Provinsi Sulawesi Selatan. Data primer dikumpulkan melalui wawancara terhadap pemanfaat sumber daya; sedangkan data sekunder berupa jumlah populasi pemanfaat (nelayan) di sekitar kawasan, jumlah wisatawan dan luas kawasan dikumpulkan melalui penelusuran literatur dan laporan-laporan yang tersedia. Analisis data dilakukan menggunakan teknik valuasi ekonomi sumber daya, yaitu teknik Effect on Production dan Zonal Travel Cost Method. Hasil kajian menunjukkan bahwa nilai manfaat ekonomi ekosistem terumbu karang di TWP Kapoposang adalah sebesar Rp1.698.945.542,-/ ha/tahun; sedangkan nilai ekonomi wisata di TWP Kapoposang adalah sebesar Rp467.753.989,-/ha/tahun. Nilai ekonomi manfaat wisata terlihat kontradiksi jika dibandingkan dengan total nilai kesediaan membayar (U) yang dibayarkan oleh pengunjung sebesar Rp2.012,-/ pengunjung/tahun, yang mengindikasikan penghargaan pengunjung terhadap sumber daya terumbu karang relatif rendah. Pengembangan pariwisata pada kawasan konservasi khususnya di TWP Kapoposang sangat penting dilakukan agar memberikan dampak atau manfaat ekonomi yang tinggi, sehingga pemanfaatan yang bersifat ekstraksi sumber daya pada kawasan konservasi dapat berkurang.
\end{abstract}

Kata Kunci: nilai ekonomi; terumbu karang; wisata; Kapoposang

\section{ABSTRACT}

Assessment of economic value of ecosystems in the conservation areas is very important as a basis for consideration of management marine conservation areas. This study aims to estimate the economic value of coral reef ecosystems in Kapoposang Aquatic Tourism Park, South Sulawesi Province. Primary data was collected through interviews with resource users and secondary data in the form of number of users (fishers) around the area, size of the area itself and number of tourists were collected through literature studies and compiled the available report. Data were analysedusing economic valuation techniques, namely Effect on Production and Zonal Travel Cost Method techniques. Results of the study show that the value of the economic benefits of the coral reef ecosystem in the Kapoposang TWP was IDR 1,698,945,542/ha/year whereas for the tourism in Kapoposang TWP was IDR 467,753,989/ ha/year. This values were contradicted with the current amount of money paid by tourist visitors of IDR 2.012/ visitorlyear of which considered their willingness to pay $(U)$ to the resource. The development of tourism in conservation areas, especially in the Kapoposang TWP, is very important to be carried out in order to provide high economic impact or benefits so that the extraction resources utilization in the conservation areas can be reduced.

Keywords: economic value; coral reef; tourism; Kapoposang 


\section{APLIKASI MODEL PELLA -TOMLINSON PADA PENGELOLAAN SUMBER DAYA PERIKANAN KAKAP MERAH DI INDONESIA \\ Pella-Tomlinson Model for Red Snapper Management in Indonesia}

Sonny Koeshendrajana, Mira, Zuzy Anna, Duto Nugroho, Umi Muwamanah dan Yesi Dewita Sari

\section{ABSTRAK}

Tujuan dari penelitian ini adalah memodelkan pengelolaan sumber daya perikanan kakap merah di Indonesiadengan menggunakan model Pella-Tomlinson. Penelitian ini dilakukan pada tahun 2016, dengan data perikanan kakap merah Indonesia. Model surplus produksi bio-ekonomi yang digunakan dalam penelitian ini adalah model Pella-Tomlinson. Hasil analisis mengindikasikan, pertama jumlah upaya tangkap aktual berada diatas jumlah jumlah upaya lestari (MSY). Jika pengelolaan perikanan dilakukan berdasarkan prinsip perikanan lestari, maka mulai tahun 2020 upaya tangkap di bawah jumlah upaya lestari (MSY). Kedua, dalam kondisi bussiness as ussual, terjadi kenaikan bio-massa ikan semenjak tahun 1980 sampai pada tahun 2000, akan tetapi dari tahun dari tahun 2000 sampai tahun 2014 terjadi penurunan bio-massa ikan. Jika tidak ada intervensi kebijakan untuk mengurangi laju degradasi sumber daya maka penurunan biomassa akan terus terjadi hingga tahun 2050. Jika pemerintah melakukan intervensi kebijakan pengelolaan perikanan secara berkelanjutan, akan terrjadi kenaikan biomassa dari tahun 2020 sampai dengan tahun 2050. Ketiga, sejalan dengan penurunan bio-massa karena tidak adanya intervensi kebijakan pengelolaan perikanan kakap merah secara berkelanjutan, maka keuntungan yang diterima nelayan akan menurun, karena terjadi penurunan hasil tangkapan. Tapi jika pemerintah mengeluarkan kebijakan pengelolaan perikanan kakap merah secara berkelanjutan seperti pembatasan upaya penangkapan, maka keuntungan yang diterima nelayan akan meningkat lagi dari tahun 2020 sampai dengan tahun 2050.

Kata Kunci: pella-tomlinson; pengelolaan; sumber daya; kakap merah

\section{ABSTRACT}

The purpose of this study to develop a management model for red snapper fishery using a Pella Tomlinson Model. The research was conducted in 2016, for the national snapper fisheries obtained from official yearly landing statisctic data to get the time series catches and efforts. Surplus production bioeconomic was utilized with modified Pella and Tomlinson model for the growth model. The analysis shows that first, total efforts deployed without any kind of management (e.g. stay as an open access) will yield higher effort than maximum efforts at maximum sustainable level yield (MSY). This is a consequence of the increasing rate of red snapper efforts between 1980-2014. If fishery management is kept at the sustainable level of total efforts, then in 2020, total efforts will be less than the MSY level. Second, biomass increased between 1980-2000 and then decreased after 2000 until 2014. If there will be no intervention to the depletion of fishery resources, the fishery will be completely depleted in 2050. Third, when the snapper biomass decreases, the cathes will decrease as well. Hence, that total profits from the fishery will decrease. However, some intervention and magement measures will be put in place, such as limiting the total efforts, the cathes and profits will bounce back and increase after 2020 and the years after.

Keywords: pella-tomlinson;management; resources; red snapper 


\section{STRATEGI PENGELOLAAN PERIKANAN DI WADUK SEMPOR, KABUPATEN KEBUMEN, PROVINSI JAWA TENGAH \\ Fisheries Management Strategies In The Sempor Reservoir Of Kebumen Regency, Central Java Province}

Tenny Apriliani, Nendah Kurniasari dan Christina Yuliaty

\section{ABSTRAK}

Waduk Sempor merupakan salah satu tipologi sumber daya perairan umum daratan yang bersifat multiguna, yang salah satu pemanfaatannya adalah untuk perikanan baik perikanan tangkap maupun budidaya. Tulisan ini bertujuan untuk merumuskan strategi yang tepat dalam pengelolaan perikanan di Waduk Sempor, Kabupaten Kebumen. Kegiatan penelitian ini dilakukan pada tahun 2016, data dikumpulkan melalui observasi yang kemudian dianalisis secara kualitatif dengan pendekatan deskriptif. Hasil penelitian menunjukkan bahwa berdasarkan pengaruh (power) dan kepentingannya (interest), maka stakeholders dalam pengelolaan perikanan di Waduk Sempor dapat dikategorikan menjadi dua yaitu key players dan crowd. Stakeholders yang termasuk dalam kategori key players adalah Dinas Kelautan dan Perikanan (DKP) Kabupaten Kebumen, Balai Besar Wilayah Sungai (BBWS) Serayu Opak, Kebumen Dinas Kebudayaan dan Pariwisata, Dinas Sumberdaya Air dan Energi Mineral (DSA) Kebumen dan masyarakat. Pemangku kepentingan yang termasuk dalam kategori kerumunan adalah DKP Prov. Jawa Tengah, Perusahaan Hutan Negara Indonesia (Perhutani) Kebumen, Perusahaan daerah Air Minum (PDAM) Kebumen, PT. Indonesia Power, lembaga penelitian dan universitas serta Lembaga Swadaya Masyarakat (LSM) lokal. Masyarakat khususnya nelayan di Waduk Sempor tergolong sebagai stakeholder primer karena berkepentingan secara langsung terhadap sumberdaya perikanan yang terdapat di Waduk Sempor, serta memiliki pengaruh dalam pengelolaan. Pengaruh (power) masyarakat dalam pengambilan keputusan dalam pengelolaan perikanan di waduk Sempor tergolong cukup. Pemanfaatan dan pengelolaan sumber daya perikanan di perairan umum waduk dapat direkomendasikan dengan cara menerapkan unsurunsur ko-manajemen yang terpadu dengan program pengembangan perikanan tangkap berbasis budidaya (Culture Based Fishery-CBF).

Kata Kunci: analisis stakeholder; pengelolaan perikanan waduk; culture based fisheries

\section{ABSTRACT}

Sempor Reservoir is one of inland water typologies with multipurpose utilizations, one of which is for fisheries, both capture fisheries and aquaculture. The aimed of this paper is to formulate an appropriate strategy of fisheries management in Sempor Reservoir, Kebumen Regancy through the impelementation of Culture Based Fisheries Program (CBF). This research was conducted in 2016 and data was collected through observation and interview. Data was analyzed quatitatively with descriptive approached. The results showed that based on the influence (power) and interests (interest), then stakeholders in fisheries management in Sempor Reservoir can be categorized into two key players and Crowd. Stakeholders included in the key players category are Marine and Fisheries Agency (DKP) Kebumen Regency, River Region Agency (BBWS) Serayu Opak, Department of Culture and Tourism Kebumen, Water and Mineral Resources Agency (DSA) Kebumen and community. Stakeholders belonging to the crowd category are DKP Prov. Central Java, State Forest Company of Indonesia (Perhutani) Kebumen, Kebumen Water Company (PDAM), PT. Indonesia Power, research institutes and universities as well as local non-governmental organizations (NGOs). The community, especially fishers in Sempor Reservoir, classified as primary stakeholders because of direct interest to fishery resources contained in the Sempor Reservoir, and has influence in the management. The influence (power) of the community in making decisions in fisheries management in Sempor Reservoir is sufficient. Utilization and management of fishery resources in the general waters of the reservoir can be recommended by applying the elements of co-management integrated with the development Culture Based Fishery program (CBF).

Keywords: stakeholder analysis; fisheries management and reservoir; culture based fisheries 


\title{
DEPLESI SUMBER DAYA IKAN TUNA DAN CAKALANG DI INDONESIA Tuna And Skipjack Resources Depletion In Indonesia
}

\author{
Maulana Firdaus, Akhmad Fauzi dan A Faroby Falatehan
}

\begin{abstract}
ABSTRAK
Tuna dan cakalang memiliki potensi ekonomi yang besar di Indonesia. Beberapa penelitian menunjukkan bahwa kedua komoditas ini telah menunjukkan gejala over fishing di dunia, termasuk Indonesia. Penelitian ini bertujuan untuk mengestimasi seberapa besar deplesi ikan tuna dan cakalang di Indonesia. Deplesi sumber daya dihitung melalui perkiraan stok dan tingkat hasil lestari dengan menggunakan model produksi surplus dan estimasi parameter menggunakan metoda Clarke Yoshimoto Pooley (CYP). Nilai deplesi diperoleh dari perkalian volume deplesi dengan unit rent. Hasil penelitian menunjukkan bahwa volume rata-rata deplesi sumber daya ikan tuna dan cakalang pada periode 1992-2015 adalah (-) 2.828 ton per tahun. Rata-rata nilai deplesi sumber daya ikan tuna dan cakalang menunjukkan angka negatif, yaitu (-) Rp131,89 miliar per tahun. Nilai negatif ini menunjukkan bahwa selama periode 1992-2015, stok sumber daya ikan tuna dan cakalang mengalami penurunan sebesar 2.828 ton per tahun dengan nilai potensi kerugian atau kehilangan akibat penurunan stok yang mencapai Rp131,89 miliar per tahun.
\end{abstract}

Kata Kunci: deplesi; sumber daya; cakalang; tuna

\begin{abstract}
Tuna and Skipjack has a great economic potential in Indonesia. Several studies have shown that these commodities have symptomed of over-fishing in the world, including Indonesia. This study aims to estimate the extent of tuna and skipjack depletion in Indonesia. Resource depletion is calculated through stock estimates and sustainable yield levels using surplus production model and parameter estimation of Clark Yoshimoto Pooley (CYP) method. Depletion value is obtained from multiplication of depletion volume with unit rent. Results of the study showed that the average volume of depletion of tuna and skipjack resources in the period 19922015 was (-) 2,828 tons per year. The average value of tuna and skipjack resource depletion showed negative numbers, ie (-) IDR 131.89 billion per year. This negative value indicates that during the period 1992-2015, the stock of tuna and skipjack fish resources decreased by 2.828 tons per year with the potential value of loss or loss due to a decrease in stock which reached IDR131,89 billion per year.
\end{abstract}

Keywords: depletion; resources; skipjack; tuna

\section{FAKTOR PRODUKSI DAN PERKEMBANGAN PRODUKSI USAHA BUDIDAYA RUMPUT LAUT KOTONI DI KABUPATEN SERAM BAGIAN BARAT \\ Production Factors And Development Of The Cottoni Seaweed Cultivation In Western Seram Regency}

\author{
Robert Pensa Maryunus, Johanes Hiariey dan Yoisye Lopulalan
}

\begin{abstract}
ABSTRAK
Budidaya rumput laut kotoni merupakan komoditas unggulan Kabupaten Seram Bagian Barat yang mendapat atensi pemerintah dalam pengembangannya. Penelitian ini bertujuan untuk mengkaji faktor-faktor produksi dan perkembangan produksi usaha budidaya rumput laut di Kabupaten Seram Bagian Barat. Analisis dilakukan dengan metode deskriktif kuantitatif dan kualitatif. Hasil kajian faktor-faktor produksi menunjukkan lahan yang dinyatakan layak bagi usaha budidaya rumput laut tingkat pemanfaatannya masih sangat rendah. Material dan sarana penunjang serta bibit tersedia dan cukup mudah diperoleh. Sumberdaya manusia pembudidaya tersedia dan dengan dominasi tingkat pendidikan yang relatif rendah yakni sekolah dasar. Hasil kajian perkembangan volume produksi menunjukkan trend penurunan sejak tahun 2009. Kualitas produksi rumput laut kering yang dihasilkan pembudidaya secara umum mutunya masih
\end{abstract}

\section{ABSTRACT}

The cultivation of cottoni seaweed is priority commodity of Western Ceram Regency which gets attention by government in its development. This study was aimed to examine the factors of production and development of red seaweed cultivation production business in West Ceram District. The analysis is done by quantitative and qualitative descriptive methods. Result of the study on factors of production shows that suitable land for red seaweed cultivation utilization is still very low. Supporting materials and facilities and also seeds are available and easily accessible. Human resources of farmers are available; however, a relatively low level of education at background with dominantly primary schools. While the results of the study of the development of production volume shows a decreased trend since 2009, in general the quality of dried seaweed production produced by farmers is still low and it is not 
rendah dan belum sesuai dengan spesifikasi pabrikan dan eksportir. Untuk pengembangan usaha dibutuhkan ekstensifikasi lahan, pembinaan mutu produk serta upaya menstabilkan harga jual rumput laut kering.

Kata Kunci: faktor produksi; perkembangan produksi; budidaya rumput laut; seram bagian barat in accordance with the specifications of manufacturers and exporters. For business development, it requires land extensification, coaches of increase product quality and efforts to stabilize price.

Keywords: production factors; production development; seaweed cultivation; Western Seram

\title{
POTENSI PASAR IKAN SAGELA ASAP (Hemirhamphus sp.) DI PROVINSI GORONTALO Potency Of Smoked Halfbeaks's Market (Hemirhamphus sp.) In The Gorontalo Province
}

\author{
Ni'mawati Syariah dan Asruddin
}

\section{ABSTRAK}

Keterbatasan informasi dan data mengenai nilai ekonomis dan potensi pemasaran ikan sagela asap di Provinsi Gorontalo menjadi dasar utama penelitian ini. Penelitian ini bertujuan untuk mengetahui potensi pasar, ramalan pasar, peluang pasar dan saluran tata niaga ikan sagela asap di Provinsi Gorontalo. Penelitian ini dilaksanakan di propinsi Gorontalo pada Bulan Januari- Agustus 2018. Jenis penelitian yang digunakan adalah survei dengan responden yaitu produsen sebanyak 8 orang, pedagang besar 6 orang, IKM 2 orang dan pedagang pengecer dan konsumen akhir sebagai data pendukung yang jumlahnya disesuaikan dengan kondisi suatu lokasi. Penelitian ini dilakukan dengan menggunakan daftar pertanyaan sebagai alat pengumpulan data. Data dianalisis dengan menghitung total potensi pasar ikan sagela asap di daerah penghasil sagela dan daerah pemasaran ikan sagela asap yang ada di Propinsi Gorontalo, kemudian menghitung ramalan pasar dan peluang pasar usaha ikan sagela asap yang ada di Propinsi Gorontalo. Hasil penelitian menunjukkan bahwa potensi pasar ikan sagela asap yang ada di propinsi Gorontalo sebanyak $64.410 \mathrm{jepit} / \mathrm{bln}$ dengan estimasi nilai rupiah sebesar Rp1.301.500.000,-/bln, ramalan pasar ikan sagela asap sebanyak 40.710 jepit/bln dan peluang pasar ikan sagela asap sebanyak 23.700 jepit/bln. Bentuk Saluran tata niaga ikan sagela asap yang ada di propinsi Gorontalo yaitu mulai dari produsen baik itu produsen lokal maupun produsen luar provinsi kemudian menjualnya ke pedagang besar, IKM dan pedagang pengecer untuk seterusnya ke konsumen akhir baik itu konsumen lokal maupun konsumen luar propinsi.

Kata Kunci: potensi pasar; ramalan pasar; peluang pasar; ikan sagela asap

\section{ABSTRACT}

Information and data limitation on economic value and marketing potential of smoked halfbeaks in Gorontalo Province are the main basis of this research. This study aims to determine the market potential, market forecast, market opportunities and trade channels for smoked halfbeaks in Gorontalo Province. This research was carried out in Gorontalo Province in January-August 2018. The type of research used was a survey with respondents, namely eight producers, six large traders, two small and medium scale industries, retailers and end consumers as supporting data adjusted for local conditions. This research was conducted using a questionnaire as data collection tool. The data were analyzed by calculating the total market potential of smoked halfbeaks in the halfbeaks producing area and marketing area of smoked halfbeaks in Gorontalo Province, then calculating the market forecast and market opportunities of smoked halfbeaks business in Gorontalo Province. The results showed that market potential of smoked halfbeaks in Gorontalo Province was 64,410 bundles / month with an estimated value of 1,301,500,000 rupiah/ month, the market forecast for smoked halfbeaks is 40,710 bundles / month and the market opportunity for bundles is 23,700 bundles / month. The form of the smoked halfbeaks trading system in Gorontalo Province, starting from producers, both local and outside provinces, then selling it to wholesalers, SMIs and retailers to the end consumers, both local and outside the province.

Keywords: market potential; market forecast; market opportunity; smoked halfbeaks 


\section{STRATEGI PENGURANGAN BIAYA LOGISTIK PERIKANAN LELE (Clarias sp.) Strategies To Reducing Logistics Cost Of Catfish (Clarias sp.)}

Teny Sylvia, Kuncoro Harto Widodo dan Dyah Ismoyowati

\begin{abstract}
ABSTRAK
Ikan lele merupakan high perishable product yang membutuhkan penanganan khusus sehingga menimbulkan biaya logistik kepada konsumen. Penelitian ini dilakukan untuk menganalisis biaya logistik di sepanjang rantai pasok perikanan lele dan menyusun strategi untuk pengurangan biaya logistik tersebut. Penelitian ini berlokasi di Kabupaten Sleman, Kulon Progo, dan Bantul D.I. Yogyakarta pada bulan Januari hingga Maret 2018. Data diperoleh dengan melakukan in-depth interview kepada 30 responden yang ditentukan dengan purposive sampling dan snowball sampling. Adapun metode untuk perhitungan dan analisis biaya logistik adalah activity-based costing ( $\mathrm{ABC}$ ) sedangkan metode untuk penyusunan strategi adalah activity-based management (ABM). Hasil perhitungan biaya logistik menunjukkan bahwa aktivitas procurement memiliki beban biaya tertinggi yaitu sebesar $90,012 \%$ dari total biaya keseluruhan. Adapun rekomendasi strategi yang dapat dilakukan untuk pengurangan biaya logistik adalah menggunakan pakan tambahan untuk tier petani ikan, menerapkan pull stretegy untuk tier pengepul, dan menerapkan few supplier yang bersikap responsif dan fleksibel untuk tier pengecer.
\end{abstract}

Kata Kunci: pembiayaan berdasarkan aktivitas; manajemen berdasarkan aktivitas; perikanan lele; strategi pengurangan biaya; biaya logistik; rantai pasok

\section{ABSTRACT}

Catfish is a high perishable product that requires special handling so certainly lead to logistics costs to consumers. This study was conducted to analyze the logistics costs along catfish supply chain and develop strategies for reducing logistics costs. This research was located in Sleman, Kulon Progo, and Bantul Regency of D.I. Yogyakarta and conducted in January to March 2018. Data were obtained by in-depth interview to 30 respondents determined by purposive sampling and snowball sampling. The method for calculating and analyzing logistics costs is activity-based costing ( $A B C)$ while the method for strategy development is activity-based management (ABM). Results of logistics calculation costs indicate that procurement activities have the highest cost, which is equal to $90.012 \%$ of total cost. The recommended strategies for reducing logistics costs are using additional feed for fish farmers, implementing pull strategy for collectors, and applying a few suppliers that are responsive and flexible for retailers.

Keywords: activity-based costing; activitybased management; catfish fisheries; cost reduction strategy; logistics cost; supply chain

\section{MITIGASI RISIKO PADA RANTAI PASOK HULU IKAN SCOMBRIDAE SEGAR DI PELABUHAN PERIKANAN PANTAI TEGAL, JAWA TENGAH \\ Risk Mitigation Of Fresh Scombridae Fish In The Upstream Supply Chain In The Fishing Port Of Tegal, Central Java}

Anjar Kistia Purwaditya, Kuncoro Harto Widodo dan Makhmudun Ainuri

\section{ABSTRAK}

Ikan scombridae segar adalah produk yang memiliki nilai ekonomis tinggi dan banyak dimanfaatkan potensinya di Pelabuhan Perikanan Pantai (PPP) Tegalsari Tegal. Jumlah produksi yang turun akibat praktik Illegal Unreported and Unregulated (IUU) menyebabkan ketersediaannya tidak menentu. Sifatnya yang sensitif terhadap perubahan suhu menjadikannya mudah rusak. Kondisi yang demikian diperburuk oleh proses penanganan ikan scombridae segar yang buruk, sehingga pasokan ikan berkualitas semakin berkurang. Belum adanya strategi mitigasi terhadap potensi risiko menjadikan rantai pasok ikan scombridae segar Kota Tegal rentan terhadap gangguan ketidakpastian. Penelitian ini bertujuan untuk mengidentifikasi dan

\section{ABSTRACT}

Fresh scombridae fish has high economic value and widely utilized its potential in Pelabuhan Perikanan Pantai (PPP) Tegalsari Tegal City. However, its availability in the field is uncertain which is the impact of decreasing production amount due to illegal, unreported, and unregulated (IUU) practices. This fish is sensitive to temperature changing and easily damaged. Such conditions are exacerbated by the poor handling of fresh fish, thus cause the supply of fresh fish with best quality is slightly reduced. The absence of a mitigation strategies against potential risks cause the fresh scombridae fish supply chain is vulnerable to uncertainty disturbance. This research aims to identify and analyze the risks event, risk agent and generates a risk mitigation strategy in the 
menganalisis kejadian risiko, sumber risiko dan menghasilkan strategi mitigasi risiko pada rantai pasok ikan scombridae dari sudut pandang collector traders. Metode yang digunakan untuk mengidentifikasi potensi risiko adalah house of risk (HOR) yang diawali dengan proses pemetaan aktivitas bisnis menggunakan supply chain operations reference (SCOR) model. Setelah potensi risiko teridentifikasi, selanjutnya dilakukan analisis menggunakan matrik HOR1. Selanjutnya, strategi mitigasi dirancang dan dianalisis menggunakan HOR2. Hasil penilitian menunjukkan terdapat 22 kejadian risiko dan teridentifikasi sebanyak 25 sumber risiko. Terdapat lima sumber risiko yang kritis berdasarkan nilai agregat risk potential (ARP) terbesar. Berdasarkan analisis pemilihan tindakan mitigasi, diajukan lima usulan tindakan mitigasi untuk dilaksanakan oleh traders keluarga ikan scombridae segar.

Kata Kunci: aggregate risk potential; house of risk; rantai pasok; mitigasi risiko; ikan scombridae fresh scombridae fish supply chain from perspective of the collector traders. Method that used in this research to identify potential risk was house of risk (HOR), its begin by mapping all business activities through supply chain operations reference (SCOR) model. Then followed by HOR1 matrik to analyze potential risk. Furthermore, mitigation actions are deployed and analyzed using HOR2. For the result showed 22 risk events and 25 risk agents are identified. There are five most critical risk agents which derived from the highest aggregate risk potential (ARP). There are five mitigation actions proposed to be implementeds.

Keywords: aggregate risk potential; house of risk; supply chain; mitigation risk; scombridae fish

\title{
PERAN PRODUKTIF WANITA PESISIR DALAM MENUNJANG USAHA PERIKANAN DI KECAMATAN TEMPURAN, KABUPATEN KARAWANG \\ Productive Role Of Coastal Women In Supporting Fishery Business In The Tempuran Sub Regency, Karawang Regency
}

\author{
lin Siti Djunaidah dan Nayu Nurmalia
}

\section{ABSTRAK}

Wanita pesisir di beberapa wilayah Indonesia telah terbukti memiliki peran produktif dalam menunjang kehidupan keluarganya. Penelitian ini dilakukan di Kecamatan Tempuran Kabupaten Karawang pada bulan Oktober sampai November 2017. Penelitian ini bertujuan untuk mengidentifikasi pekerjaan yang dilakukan wanita pesisir pada sektor perikanan, tingkat pendapatan, serta kontribusi pendapatan wanita pesisir terhadap pendapatan keluarga. Metode penelitian yang digunakan adalah metode survei dengan responden wanita pesisir yang melakukan aktivitas dalam sektor perikanan. Data dikumpulkan dengan menggunakan kuesioner dari sampel secara terpilih, kemudian dianalisis dengan menggunakanmetodedeskriptifkuantitatif. Hasilpenelitian menunjukkan bahwa mayoritas umur wanita pesisir (31-50 tahun) masuk dalam kategori usia produktif. Sebanyak $75 \%$ dari wanita pesisir berpendidikan Sekolah Dasar. Aktivitas wanita pesisir mayoritas $(71,9 \%)$ sebagai buruh pengolahan hasil perikanan baik produk ikan asin dan atau terasi. Sebanyak $25 \%$ wanita pesisir beraktivitas sebagai pedagang hasil perikanan (ikan segar, ikan asin, dan terasi); sejumlah $3,1 \%$ merupakan buruh pengolahan dan pedagang hasil perikanan. Tingkat pendapatan wanita pesisir berkisar antara Rp665.000.s.d. Rp6.890.000,-. Kontribusi pendapatan wanita pesisir terhadap pendapatan keluarga berkisar

\section{ABSTRACT}

Coastal women in several regions of Indonesia has been shown to have a productive role in supporting the lives of their families. This research was conducted in Tempuran Sub Regency, Karawang Regency in October until November 2017. This study aims to identify the work undertaken by coastal women in the fisheries sector, income level, and the contribution of coastal women's income to family income. Research method used a survey method with respondents who do activity in fishery sector. Data were collected using questionnaire from selected sample, then were analyzed by using quantitative descriptive method. Results showed that the majority of coastal women was age (31-50 years) included in the category of productive age. As many as $75 \%$ of coastal women are educated Elementary School. The activity of majority of coastal women $(71,9 \%)$ as laborer of processing of fishery product both salted fish and or shrimp paste. As many as $25 \%$ of coastal women are active as fishery traders (fresh fish, salted fish and shrimp paste); $3,1 \%$ are processing laborers and traders of fishery products. This condition shows that the role of women as economic actors cannot be ignored, so that their capacity is needed to support women's role in carrying out productive economic activities. Income level of coastal women ranges from IDR 665,000 until IDR 6,890,000 rupiah. Contribution of coastal women's income to family income ranges from $32.8 \%$ to $80.6 \%$ 
antara $32,8 \%$ hingga $80,6 \%$ dengan rata-rata kontribusi $64,9 \%$. Kondisi ini menunjukkan bahwa peranan wanita sebagai pelaku ekonomi tidak bisa diabaikan, sehingga diperlukan penguatan kapasitasnya untuk menunjang peran wanita dalam melaksanakan kegiatan ekonomi produktif.

Kata Kunci: peran; wanita pesisir; usaha perikanan; pendapatan; kontribusi with an average contribution of $64.9 \%$. This condition shows that women role as economic actors cannot be ignored, so that the capacity of coastal women needs to be strengthened to support women's role in carrying out productive economic activities.

Keywords: role; coastal women; fishery business; income; contribution

\section{HUTANG SEBAGAI PENGIKAT HUBUNGAN NELAYAN DAN 'PENGAMBE' DI KABUPATEN JEMBER, PROVINSI JAWA TIMUR}

\section{Debt As A Binding Relationship Between Fishers And 'Pengambe'}

In The Jember Regency, East Java Province

Rizky Muhartono dan Nurlaili

\section{ABSTRAK}

Nelayan memiliki keterbatasan modal untuk memenuhi kebutuhan investasi dan biaya operasional. Kondisii ini berimplikasi terhadap kelangsungan usaha yang dimiliki. Salah satu strategi yang dilakukan oleh nelayan untuk memenuhi kebutuhan modal adalah dengan cara berhutang. Sumber hutang nelayan didapat dari 'pengambe'. Tujuan penelitian ini adalah untuk mengkaji permasalahan hutang sebagai pengikat hubungan nelayan dan "pengambe'.. Penelitian dilakukan pada tahun 2015 di Kabupaten Jember Provinsi Jawa Timur. Data primer dan sekunder digunakan dalam penelitian ini. Pengumpulan data dilakukan melalui wawancara mendalam dan studi literatur. Analisis data dilakukan secara deskriptif kualitatif. Hasil penelitian menunjukkan bahwa nelayan membutuhkan 'pengambe' untuk menambah kekurangan modal untuk membeli perahu, alat tangkap, dan pemasaran ikan. 'pengambe' menjadi penolong, namun ikatan hutang membuat nelayan terikat dan tidak dapat bebas menentukan harga. Rekomendasi yang diberikan adalah perlu diperkuat program pemberdayaan ekonomi dan lembaga permodalan di lokasi sehingga dapat bersinergi dengan 'pengambe' . 'pengambe' menjadi salah satu aktor yang harus dilibatkan dalam rancangan dan implementasi pengembangan kelembagaan ekonomi masyarakat lokal. Pengalihan wewenang dan dan tanggung jawab 'pengambe' kepada lembaga permodalan lokal harus dilakukan secara perlahan dan bertahap sehingga tidak menimbulkan konflik kepentingan. 'pengambe' tidak kehilangan mata pencaharian dan nelayan dapat menjadi mandiri mengakses modal seiring dengan peningkatan kemampuannya merencanakan dan mengelola keuangan.

Kata Kunci: hutang; nelayan; 'pengambe'; Jember

\section{ABSTRACT}

Fishers have limited capital to fulfill the need of investment and operational costs of fishing activity. These conditions imply to the sustainability of their business. Debt is one of fishers' strategy to meet the capital needs, and it is obtained from the "pengambe'. Purpose of the study was to evaluate debt problems as a binding relationship between fishers and "pengambe'. Research was conducted in 2015 in Jember Regency, East Java Province. This study used primary and secondary data and they were collected through in-depth interviews and literature studies. Data were analyzed with qualitative descriptive method. The results showed that fishers need 'pengambe' to provide them with capital to buy boats, fishing gear and fish marketing. 'Pengambe' is a helper for the fishers, but they become strictly bounded and consequently incapable to determine fish prices. This study recommends the necessity to encourage economic empowerment program and local capital institutions to have a mutual relationship with 'pengambe'. 'Pengambe' should be involved in local economic institution development design and implementation. Authority transfer and responsibility of 'pengambe' to the local capital institution should be executed in a gradual step to avoid conflict of interest. Therefore, 'pengambe' not lose their livelihoods and fishers able to self-access capital along with ability improved to plan and manage their finance.

Keywords: debt; fishers; 'pengambe'; Jember 


\section{(Indeks Pengarang)}

(Author Index)

Ainuri, Makhmudun

219-227

Anna, Zuzy.....

143-152

Apriliani, Tenny

153-166

Asruddin.

193-203

Djunaidah, lin Siti

229-237

Falatehan, A Faroby

167-178

Fauzi, Akhmad

167-178

Firdaus, Maulana

133-142

167-178

Hiariey, Johanes

179-192

Ismoyowati, Dyah

205-218

Koeshendrajana, Sonny

153-166

Kurniasari, Nendah

$1-10$

Lopulalan, Yoisye

179-192

Maryunus, Robert Pensa

179-192

Mira.

143-152

Muawanah,Umi

143-152

Muhartono, Rizky

239-248

Muliawan, Irwan.

133-142

Nugroho,Duto

143-152

Nurlaili

239-248

Nurmalia, Nayu

229-237

Purwaditya, Anjar Kristia

219-227

Sari, Yesi Dewita

219-227

Syariah, NI'matin

193-203

Sylvia, Teny

205-218

Widodo, Kuncoro Harto

219-227

205-218

Yuliaty, Christina

153-166 
(Indeks Subjek)

(Index Subject)

Aggregate risk potential

219-227

Analisis stakeholder

153-166

Biaya logistik

205-218

Budidaya rumput laut

179-192

Cakalang

167-178

Culture based fisheries

153-166

Deplesi

167-178

Faktor produksi

179-192

House of risk

219-227

Hutang

239-248

Ikan sagela asap

193-203

Ikan scombride

219-227

Jember

239-248

Kakap merah

143-152

Kapoposang

133-142

Kontribusi

229-237

Manajemen berdasarkan aktivitas

205-218

Mitigasi risiko

219-227

Nelayan

239-248

Nilai ekonomi

133-142

Pella-tomlinson

143-152

Peluang pasar

193-203

Pembiayaan berdasarkan aktivitas

205-218

Pendapatan

229-237

Pengambe

239-248

Pengelolaan

143-152

Pengelolaan perikanan waduk

153-166

Peran

229-237

Perikanan lele

205-218

Perkembangan produksi

179-192

Potensi pasar

193-203

Ramalan pasar

193-203

Rantai pasok

205-218

179-192

Seram bagian barat

179-192

Sumber daya

Terumbu Karang

133-142

Tuna

167-178

Usaha perikana

Wanita pesisir

Wisata 


\section{JURNAL SOSIAL EKONOMI KELAUTAN DAN PERIKANAN \\ Pedoman Bagi Penulis}

Jurnal Sosial Ekonomi Kelautan dan Perikanan memuat hasil-hasil penelitian yang berkaitan dengan penelitian bidang sosial dan ekonomi kelautan dan perikanan. Naskah yang diterima yaitu karya tulis yang merupakan karya asli dan belum pernah diterbitkan dipublikasi lainnya.

\section{UMUM}

Kertas : HVS A4 $(21,0 \times 29,7 \mathrm{~cm})$

Margin : Kiri $3 \mathrm{~cm}$

Bawah, Kanan dan Atas $2 \mathrm{~cm}$

Huruf : Arial, 11 pt, hitam, 1,5 spasi. ketik dalam Bahasa Indonesia (kecuali abstrak) atau Bahasa Inggris yang baik dan benar, tidak diperkenankan menggunakan singkatan yang tidak umum.

Struktur : Judul, Abstrak, Pendahuluan, Metodologi, Hasil dan Pembahasan, Kesimpulan dan Implikasi Kebijakan, Ucapan Terima Kasih dan Daftar Pustaka

Naskah dikirim melalui Online di alamat web http://ejournal-balitbang.kkp.go.id index.php/sosek atau alamat ke Redaksi Pelaksana Jurnal Sosial Ekonomi Kelautan dan Perikanan, Gedung Balitbang KP I, Komplek Bina Samudera, JI. Pasir Putih I Ancol Timur, Jakarta 14430, telp (021) 64700924, fax (021) 64711583, Email: pt.sosek@gmail.com

\section{PENULISAN NASKAH}

Naskah ditulis rapi dengan panjang naskah maksimum 20 halaman (termasuk gambar dan tabel) dan setiap lembar tulisan diberi nomor halaman.

\section{Judul}

Judul harus ditulis secara ringkas (maksimal 15 kata), tetapi cukup informatif untuk menggambarkan isi tulisan. Ditulis dalam Bahasa Indonesia dan di bawahnya dalam Bahasa Inggris, menggunakan huruf Arial, kapital Bold, 12 pt, center.

\section{Penulis dan institusi}

Penulis dan Institusinya ditulis berurutan di bawah judul. Nama penulis ditulis dengan huruf Arial, kapital bold, $10 \mathrm{pt}$, center. Institusi asal (alamat, nomor telepon, nomor faksimil, serta e-mail) ditulis dengan huruf Arial, kapital dan kecil, 10 pt, center.

\section{Abstrak}

Ditulis dalam bahasa Indonesia dan bahasa Inggris, tidak lebih dari 200 kata dan hanya satu paragraf. Abstrak memberikan informasi singkat namun jelas tentang alasan penelitian dilakukan, tujuan yang ingin dicapai, metode yang digunakan, hasil yang diperoleh serta kesimpulan. ditulis dengan huruf Arial, 10 pt.

\section{Kata Kunci}

Ditulis dalam Bahasa Indonesia dan Inggris, terdiri dari 4 sampai 6 kata tulis di bawah abstrak.

\section{Pendahuluan}

Pendahuluan sebaiknya dimulai dengan menjelaskan latar belakang penelitian, perumusan masalah, kerangka teoritis, dan tujuan penelitian yang dibuat secara ringkas. 


\section{Metodologi}

Diuraikan secara rinci dan jelas mengenai lokasi dan waktu penelitian, bagaimana data diperoleh dan sumbernya serta bagaimana metode analisis datanya, jika metode yang digunakan telah diketahui sebelumnya harus dicantumkan acuannya.

\section{Hasil dan Pembahasan}

Bagian ini menyuguhkan data dan informasi yang ditemukan peneliti serta dipakai sebagai dasar penyimpulan bahkan penyusunan teori baru. Secara umum disuguhkan secara bertahap dalam tiga bagian: uraian temuan data dan informasi yang terkumpul. Sertakan data pendukung yang berupa tabel, grafik dan gambar seperlunya untuk memperjelas dan mempersingkat uraian yang harus diberikan.

\section{Kesimpulan dan Implikasi Kebijakan}

Kesimpulan diuraikan secara ringkas dan jelas mengacu pada pokok-pokok bahasan serta kemampuan mengartikulasikan temuan pokok untuk rekomendasi kebijakan, ditulis secara singkat dan jelas dalam dua atau tiga kalimat Pada intinya menegaskan apakah tujuan penelitian ini sudah tercapai atau masih ada hal-hal yang belum dicapai. Bila belum, jelaskan apa penyebabnya.

\section{Ucapan Terima Kasish}

Ucapan Terima Kasih Ditulis dengan formal, ucapan diberikan pihak tertentu, misalnya Sponsor penelitian, nama yang benar-benar terlibat dalam pelaksanaan penelitian dan ucapan tidak terlalu berlebihan.

\section{Daftar Pustaka}

Dicantumkan dalam naskah bila ada pengutipan dari sumber lain. Proporsi daftar pustaka yang diacu yaitu $80 \%$ merupakan rujukan primer dan merupakan terbitan 5 tahun terakhir. Tuliskan hanya pustaka yang dirujuk dalam makalah saja. Hindari pustaka yang bersumber pada majalah, koran, atau media lainnya yang non-ilmiah. Disusun berdasarkan abjad.

\section{Buku :}

Huda, H.M., R.A. Wijaya dan S. Koeshendrajana. 2011. Dinamika Perkembangan Sosial Ekonomi Usaha Rumah Tangga Petambak Garam. In Koeshendrajana (eds.), PANELKANAS: Dinamika Perkembangan Usaha, Pendapatan dan Konsumsi Rumah Tangga. Badan Riset Kelautan dan Perikanan. Jakarta

\section{Prosiding :}

Solihin, A., S. Koeshendrajana dan F. Y. Arthatiani. 2012. Harmonisasi Hukum Internasional Dalam Pemberantasan IUU Fishing dan Implementasinya dalam Peraturan Perundang-undangan Indonesia. In Isnansetyo et al. (eds.), Prosiding Seminar Nasional IX Tahun 2012., SE-04: 1-17. Jurusan Perikanan Fakultas Pertanian UGM. Yogyakarta.

\section{Jurnal IImiah :}

Pitcher, T.J. and D.B Preikshot. 2001. Rapfish: A Rapid Appraisal Technique to Evaluate the Sustainability Status of Fisheries. Fisheries Research. Vol 49(3): 255-270

\section{Artikel dari situs internet ;}

Sahyuti. 2012. Ciri-ciri Masyarakat Adat. http://syahyutivariabel.blogspot.com/2012/07/ciri-ciri-masyarakat-adat.html. (diakses 27 Desember 2012). 


\section{Laporan :}

Koeshendrajana, S., F. N. Priyatna, I. Mulyawan, A. Ramadhan, E. Reswati, R. Triyanti, A. Fahrudin, E. S. Kartamihardja dan C. M. Witomo. 2008. Riset Identifikasi, Karakterisasi dan Valuasi Sosial Ekonomi Sumber daya Perairan Umum Daratan. Laporan Teknis Kegiatan Penelitian. Balai Besar Riset Sosial Ekonomi Kelautan dan Perikanan. BRKP

Thesis, Disertasi :

Sufii, S. 2008. Konvergensi Ekonomi Regional di Indonesia Tahun 1985-2006. Thesis. Fakultas Ekonomi. Universitas Indonesia. Program Magister Perencanaan dan Kebijakan Publik. Jakarta

Tabel

Judul tabel (Arial, center, \& $11 \mathrm{pt}$ ) diberi nomor urut dan ditulis di atas tabel. Tabel ditulis dalam bahasa Indonesia dan Inggris, diketik menggunakan program MS-Word dan tidak dalam bentuk JPEG. Sumber dicantumkan di bawah tabel.

Contoh:

Tabel 8. Total Nilai Ekonomi Mangrove di Wilayah Pesisir Kabupaten Merauke.

Table 8. The Total Economic Value Mangrove Coastal Merauke.

\begin{tabular}{lrr}
\hline $\begin{array}{c}\text { Kategori Nilai Ekonomi/ } \\
\text { Category Economic Value }\end{array}$ & $\begin{array}{c}\text { Total Nilai/ } \\
\text { Total value (Rp/Tahun) }\end{array}$ & $\begin{array}{c}\text { Total Nilai/ } \\
\text { Total value (Rp/Ha/Tahun) }\end{array}$ \\
\hline Nilai Guna Langsung/ Direct value & $121,120,873,947$ & $11,964,919$ \\
Nilai Guna Tidak Langsung/ Indirect Value & $48,361,817,303,4$ & $4,777,419$ \\
Nilai Pilihan/ Option value & $3,074,276,220$ & 303,692 \\
Nilai Keberadaan/ The existence value & $2,134,333,320$ & 210,840 \\
Nilai Pewarisan/ Value Inheritance & $2,728,107,120$ & 269,496 \\
\hline \multicolumn{1}{c}{ Total/ Total } & $\mathbf{1 7 7 , 4 1 9 , 4 0 7 , 9 1 0}$ & $\mathbf{1 7 , 5 2 8 , 3 6 7}$ \\
\hline
\end{tabular}

Sumber/ Source : Data Primer Diolah (2015)/ Primary Data Processed (2015)

\section{Gambar}

Judul Gambar (Arial, center, \& 11 pt) diberi nomor urut dan ditulis di bawah Gambar. Gambar ditulis dalam bahasa Indonesia dan Inggris, diketik menggunakan program MS-Word dan dalam bentuk JPEG dengan kualitas gambar resolusi diatas $72 \mathrm{dpi}$. Sumber dicantumkan di bawah judul.

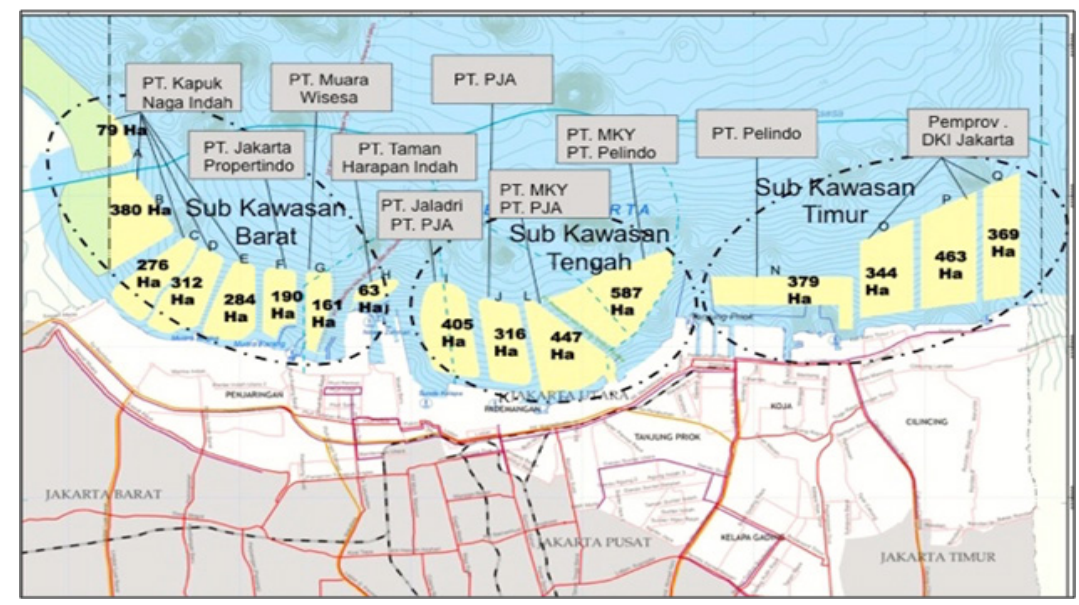

Gambar 1. Peta Wilayah Reklamasi Teluk Jakarta

Figure 1. Map of Reclamation Area of Jakarta Bay

Sumber: Kementerian Lingkungan Hidup dan Kehutanan (KLHK) dalam Mongabay/ Source: Ministry of Environmental and Forestry in Mongabay (2016) 
BALAI BESAR RISET SOSIAL EKONOMI KELAUTAN DAN PERIKANAN Gedung Balitbang KP Lt. 3

Jalan Pasir Putih Nomor 1 Ancol Timur, Jakarta Utara

Telp. (021) 6471 1583, Faks.(021) 64700924

Web : www.bbrse.kkp.go.id

email :pt.sosek@gmail.com

pt_sosek@yahoo.co.id

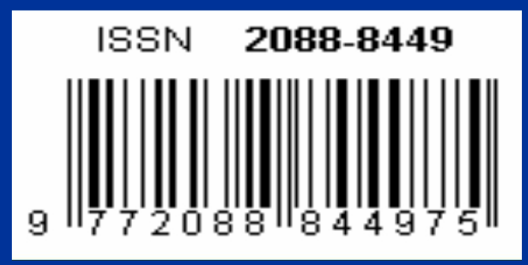

